\title{
Overvåking av norsk kosthold - metoder og resultater
}

\author{
Lars Johansson \\ Statens råd for erncering og fysisk aktivitet, Postboks 8139 Dep., 0033 Oslo \\ Telefon: 22249066 telefaks: 22249091 e-post: lars.johansson@sef.no
}

\begin{abstract}
SAMMENDRAG
Kunnskap om endringer i matvarenes sammensetning og befolkningens kosthold er grunnleggende for utforming og oppfølging av en helsefremmende mat- og ernæringspolitikk. Dagens system for overvåking av kostholdet bygger først og fremst på en matvaredatabase og opplysninger om forbruket av matvarer fra tre typer datasett; matforsyningsstatistikk, forbruksundersøkelser og kostholdsundersøkelser. Det avgis årlig en vurdering av utviklingen i norsk kosthold i forhold til mat- og ernæringspolitiske målsettinger. Det norske systemet for overvåking av kostholdet er blitt betydelig styrket i løpet av 1990-årene ved innføringen av regelmessige kostholdsundersøkelser blant landsrepresentative utvalg av befolkningen i ulike aldersgrupper og økte ressurser til analyse av næringsinnholdet i matvarer. Det er imidlertid beskjedent sammenlignet med datainnsamlingen i land som USA og Storbritannia. Det norske overvåkingssystemet er forsatt $i$ en utviklingsfase, og det må justeres og kompletteres etter hvert. Dessuten vil det arbeides med å kvalitetssikre datainnsamlingen.
\end{abstract}

\section{Johansson L. Surveillance of the diet in Norway - methods and results. Nor J Epidemiol 2000; 10 (1): 31-42.}

\section{ENGLISH SUMMARY}

Knowledge about changes in composition and intake of foods, as well as changes in the prevalence of dietrelated health problems is fundamental for an effective food and nutrition policy. The National Council on Nutrition and Physical Activity is responsible for evaluating changes in the diet. Annually the Council publishes reports about trends in the Norwegian diet, and suggests measures to improve the diet. The Council, in cooperation with the National Food Authority and the Institute for Nutrition Research, University of Oslo, has established a national food and dietary surveillance system. This system is mainly based on a food database and food consumption data. The food consumption data include three principally different data sets: food supplies, household consumption surveys, and dietary surveys. Food supplies have been published annually since 1952. Household consumption surveys among random nation-wide samples of private households have been performed annually by Statistics Norway since 1975. Dietary surveys were included on a regular basis in the surveillance system in 1993 when the first Norwegian nation-wide dietary surveys among students 13 and 18 years old and the general population aged 16-79 years were conducted. The second dietary survey among the general population was made in 1997, and the first survey among infants was performed in 1998-99. The second survey among children 5-13 years is planned for 2000-2001. The Norwegian surveillance system has been considerably improved during the 1990s. However, the collection of dietary data is still modest compared to what is done in the USA and Great Britain. The system is developing, and will be adjusted and supplemented. Quality assurance of methods will be given priority.

\section{INNLEDNING}

Kostholdet påvirker trolig mer enn noen annen miljøfaktor befolkningens helsetilstand ${ }^{1}$. Norske helsemyndigheter har derfor i en årrekke arbeidet for å minske forekomsten av kostholdsrelaterte helseproblemer. Data som viser kostholdets betydning for helsen, forekomsten av kostholdsrelaterte helseproblemer og befolkningens kosthold er grunnleggende for utformin- gen og oppfølgingen av en helsefremmende mat- og ernæringspolitikk. Behovet for å bedre innsamlingen av data som beskriver befolkningens kosthold og ernæringssituasjon har derfor vært uttrykt $i$ flere ernæringspolitiske dokumenter ${ }^{2-4}$ og flere forslag til forbedringer av datainnsamlingen ble avgitt rundt $1990^{5-9}$.

Statens råd for ernæring og fysisk aktivitet (SEF) skal ifølge sitt mandat beskrive, analysere og vurdere 
kostholds- og matforsyningssituasjonen i Norge på kortere og lengre sikt. Rådet har siden begynnelsen av 1950-årene årlig avgitt en vurdering av utviklingen i norsk kosthold. Denne rapporten baserte seg til å begynne med i hovedsak på opplysninger om engrosomsetningen av matvarer for hele landet. Fra midten av 1970-årene ble det også brukt data fra Statistisk sentralbyrås (SSB) forbruksundersøkelser i privathusholdninger ${ }^{10}$.

Det er i årenes løp gjennomført en rekke kostholdsundersøkelser, men disse var lite egnet til å beskrive utviklingen i norsk kosthold ettersom de som regel var utført på meget små grupper eller i utvalgte strøk av landet. Fram til begynnelsen av 1990-årene hadde man ikke data om kostholdet fra landsrepresentative utvalg av befolkningen. SEF, Statens næringsmiddeltilsyn (SNT) og Institutt for ernæringsforsking, Universitetet i Oslo (IE) innledet derfor et samarbeid for å styrke systemet for overvåking av kostholdet gjennom å forbedre databasen om matvarers næringsinnhold (matvaredatabasen), utvikle et nytt kostberegningssystem og å starte innsamling av data om kostholdet hos representative utvalg av befolkningen.

De tradisjonelt brukte metodene for kostholdsundersøkelser er meget ressurskrevende ${ }^{11,12}$. IE utarbeidet derfor i slutten av 1980-årene et selvadministrert maskinlesbart spørreskjema hvor den videre bearbeiding kan skje direkte med hjelp av dataprogrammer. Metoden var i 1992 bare brukt på mindre og ikke tilfeldig utvalgte grupper hvor man hadde personlig kontakt med deltakerne. Den hadde imidlertid i to valideringsstudier $^{13,14}$ vist seg å gi rimelig gode data om kostholdet sammenlignet med tradisjonelt brukte og mer kostbare metoder hvor deltakerne veier og måler alt de spiser og drikker i løpet av et bestemt antall dager ${ }^{15}$. Man besluttet derfor å teste denne metoden på grupper av tilfeldig utvalgte personer ${ }^{16}$. En variant av spørreskjemaet tilpasset bruk blant ungdom ble brukt i en landsomfattende undersøkelse av skoleelevers kosthold i $1993^{17}$.
Målsettingen med artikkelen er å gi en oversikt over SEFs system for overvåking av kostholdet, beskrive metoder og metodeutvikling for innsamling av kostholdsdata, samt beskrive norsk gjennomsnittskosthold ut fra kostholdsdata fra tre nivåer nemlig matforsyning, forbruksundersøkelser og to nasjonale kostholdsundersøkelser blant voksne.

\section{OVERVÅKING AV KOSTHOLDET}

Dagens system for overvåking av kostholdet tar utgangspunkt i oppfølgingen av mat- og ernæringspolitikken og er primært et instrument for å forbedre det helsefremmende arbeidet. Det har to sentrale byggesteiner, en matvaredatabase og data om forbruket av matvarer. Med hjelp av et kostberegningssystem kan man beregne kostens innhold av næringsstoffer (Rimestad m.fl., dette temanummeret).

De samlede kunnskapene om utviklingen i kostholdet og informasjon om kostholdsrelaterte helseproblemer danner grunnlaget for en vurdering i forhold til mat- og ernæringspolitiske målsettinger. Årlig avgis en vurdering sammen med forslag til tiltak til helsemyndighetene. Mesteparten av datainnsamlingen og videreutviklingen av systemet for overvåking av kostholdet gjøres i samarbeid mellom SEF, SNT og IE, men også andre institusjoner som Norsk institutt for landbruksøkonomisk forskning (NILF) og SSB bidrar med deler av datainnsamlingen.

Utviklingen i befolkningens kosthold er i senere år primært beskrevet med tre prinsipielt forskjellige typer datasett: matforsyningsstatistikk for hele landet, forbruksundersøkelser over anskaffelse av matvarer i privathusholdninger og nasjonale kostholdsundersøkelser over inntaket av matvarer (tabell 1). Dessuten er det gjort en rekke kostholdsundersøkelser og forbruksundersøkelser blant selekterte utvalg fra begynnelsen av vårt århundre til i dag ${ }^{18,19}$.

Matforsyningstallene utarbeides for SEF av NILF $^{10}$. De er basert på statistikk over import, eksport,

Tabell 1. Datakilder for matvareforbruk i systemet for overvåking av kostholdet.

\begin{tabular}{llll}
\hline & År & Utvalg (svarprosent) & Metode \\
\hline $\begin{array}{l}\text { Matforsynings- } \\
\text { statistikk }\end{array}$ & $\begin{array}{l}1953-98 \\
\text { årlig }\end{array}$ & & $\begin{array}{l}\text { Omsetning av matvarer } \\
\text { til hele befolkningen }\end{array}$ \\
\hline $\begin{array}{l}\text { Forbruksundersø- } \\
\text { kelser i privathus- } \\
\text { holdninger }\end{array}$ & $\begin{array}{l}1975-97 \\
\text { årlig }\end{array}$ & $\begin{array}{l}\text { Landsrepresentativt utvalg av ca. 1300 privathusholdninger } \\
\text { pr. år (58-68\%) }\end{array}$ & $\begin{array}{l}\text { Registrering av anskaf- } \\
\text { felse av matvarer i } \\
\text { husholdningen i to uker }\end{array}$ \\
\hline $\begin{array}{l}\text { Kostholdsundersøkelser i ulike aldersgrupper } \\
\text { Spedkost }\end{array}$ & $1998-99$ & $\begin{array}{l}\text { Landsrepresentativt utvalg av 3000 spedbarn undersøkt } \\
\text { ved 6 og 12 mnd alder (hhv. 80\% og 66\%) }\end{array}$ & Spørreskjema \\
\hline $\begin{array}{l}\text { Småbarnskost } \\
\text { Ungkost }\end{array}$ & 1999 & Landsrepresentativt utvalg av 3000 2 år gamle barn (58\%) & Spørreskjema \\
\hline Norkost & 1993 & Landsrepresentativt utvalg av 3269 elever 13 år og 18 år (87\%) & Spørreskjema \\
\hline Norkost & $1993-94$ & Landsrepresentativt utvalg av 3144 personer 16-79 år (63\%) & Spørreskjema \\
\hline
\end{tabular}


produksjon og omsetning av matvarer. Tallene gir informasjon om forbruk på engrosnivå av matvarer, dvs. de matvarekvanta som tilføres markedet fra produsent til første ledd på mottagersiden. Datagrunnlaget er ikke like sikkert for alle matvaregrupper. Oppgavene for korn, melk og melkeprodukter, kjøtt og margarin anses meget sikre. For poteter, grønnsaker, frukt og bær er det betydelig usikkerhet når det gjelder primærproduksjonen. Statistikken for sukker, sukkervarer, erter, nøtter og kakao bygger på Statistikk for utenrikshandelen og gjelder derfor importen. Statistikken for engrosforbruk av fisk og "annet fett" (spiseoljer, bakefettblandinger, fett og olje til produksjon av en rekke varer som majones, sauser m.v.) er meget usikker og mangelfull.

Datagrunnlaget for forbruk av fisk er forbedret ved at det er satt i gang egne undersøkelser for å måle anskaffelsen av fisk og fiskevarer i privathusholdninger. Undersøkelsene er kommet i stand som et samarbeid mellom Eksportutvalget for fisk, NILF og SEF. Registreringen gjennomføres årlig siden 1995 av GfK Norge i et panel av 1500 husholdninger. Hver husholdning deltar vanligvis i panelet $\mathrm{i}$ tre år, og fører dagbok løpende. Undersøkelsen omfatter ikke fiskemåltidene som de enkelte medlemmer av husholdningene eventuelt kjøper og spiser utenfor hjemmet.

I SSBs forbruksundersøkelser er det årlig siden 1975 registrert hvor mye mat som blir anskaffet (dvs. kjøpt, tatt av egen produksjon, fått som gave o.l.) av et landsrepresentativt utvalg av 2000-2500 privathusholdninger i løpet av 2 uker $^{10}$. Mat som blir kjøpt og spist utenfor husholdningen f.eks. i gatekjøkken, er ikke med i mengderegistreringene. Matmengden som registreres i undersøkelsen er relatert til hele husholdningen. Rapporterte kostholdsdata uttrykkes som mengde per person ved at verdier for hele husholdningen divideres med antall personer $\mathrm{i}$ husholdningen. Undersøkelsen gir informasjon om hvor mye mat som anskaffes, ikke hva som faktisk blir spist.

Fra 1993 er det gjennomført nasjonale kostholdsundersøkelser blant landrepresentative utvalg i ulike aldersgrupper (tabell 1), og 1990-årene har derfor vært preget av metodeutvikling (tabell 2). Man planlegger å gjenta de nasjonale kostholdsundersøkelsen (Spedkost, Småbarnskost, Ungkost og Norkost) omtrent hvert femte år.

Våren 1993 ble det gjennomført kostholdsundersøkelser blant et landsrepresentativt utvalg av skoleelever fra 7. klasse (13 år) og 2. trinn på videregående skole (18 år) (Ungkost-93) ${ }^{20}$. Det endelige utvalget utgjorde 3269 elever, $87 \%$ av utvalget. Kostholdet ble kartlagt med et spørreskjema med spørsmål om hvor mye og hvor ofte deltakerne spiste av 190 matvarer, matretter og grupper av matvarer. Reproduserbarheten av spørreskjemaet ble testet $i$ en gruppe av 103 18åringer, samt evaluert mot veid registrering av kostholdet i syv dager i en gruppe av 49 18-åringer. Evalueringen viste at spørreskjemaet hadde en god reproduserbarhet og at det var i stand til å rangere individer $\mathrm{i}$ forhold til de fleste næringsstoffer ${ }^{21}$. Det planlegges å gjennomføre en ny nasjonal kostholdsundersøkelse blant barn og ungdom i aldrene 5, 9 og 13 år i løpet av 2000-2001. Erfaringene fra den første Ungkostundersøkelsen tydet på at spørreskjemaet var vanskelig å besvare for 13-åringene. Derfor utvikler man nå en ny metode for bruk i aldersgruppene 5-13 år.

I 1993-94 22 og $1997^{23}$ ble det gjort kostholdsundersøkelser blant landsrepresentative utvalg av menn og kvinner i alderen 16-79 år (Norkost). Undersøkelsen 1993-94 ble gjennomført i løpet av fire perioder: juni, september og november 1993 og mars 1994, og 3144 personer $(63 \%)$ av det opprinnelige utvalget leverte brukbare svar. Undersøkelsen 1997 ble gjennomført i løpet av mars, juni, september og november 1997, og 2672 personer $(54 \%)$ av det opprinnelige utvalget leverte brukbare svar.

Tabell 2. Metodeutvikling av kostholdsundersøkelser i tilknytning til systemet for overvåking av kostholdet.

\begin{tabular}{lll}
\hline & ̊̊r & Formål med arbeidet \\
\hline Spedkost-pilot & $1997-98$ & Utvikle og teste spørreskjema blant 144 barn i alderen 6 og 12 måneder, samt 2-3 år. \\
\hline $\begin{array}{l}\text { Spedkost og } \\
\text { Småbarnskost }\end{array}$ & $1999-2000$ & $\begin{array}{l}\text { Evaluering av spørreskjema mot veid registrering av matinntaket blant barn i alderen } \\
\text { 12 og 24 måneder. }\end{array}$ \\
\hline Ungkost & $1992-93$ & $\begin{array}{l}\text { Utvikle, teste og evaluere et spørreskjema. Reproduserbarheten av spørreskjemaet ble } \\
\text { testet i en gruppe av 103 18-åringer, samt evaluert mot veid registrering av inntaket i } 7 \\
\text { dager i en gruppe av 49 18-åringer. }\end{array}$ \\
\hline Ungkost-pilot & $1999-2000$ & Utvikle og teste matdagbok blant barn i alderen 5, 9 og 13 år. \\
\hline Norkost-pilot & 1992 & $\begin{array}{l}\text { Test av distribusjonsmetoder av spørreskjema, samt belønning, i et tilfeldig utvalg av } \\
\text { 1200 personer 16-79 år fordelt på seks grupper. }\end{array}$ \\
\hline Norkost & 1996 & $\begin{array}{l}\text { Evaluere Norkostskjemaet mot veid registrering i 14 dager og fettsyrer og } \alpha \text {-tokoferol } \\
\text { i serum og fettvev blant 125 menn 20-55 år. }\end{array}$ \\
\hline Kort skjema & 1996 & $\begin{array}{l}\text { Utvikle et kort spørreskjema om kostholdet og evaluere det mot veid registrering i 14 } \\
\text { dager blant 109 menn i alderen 20-55 år. }\end{array}$ \\
\hline Kort skjema - pilot & 1996 & $\begin{array}{l}\text { Innarbeide spørsmålene i det korte spørreskjemaet i spørreskjemaet til } \\
\text { fylkesundersøkelsen i Agder blant et utvalg av ca. 16 000 personer i aldersgruppene } \\
\text { 40-42 år og 75-79 år. }\end{array}$ \\
\hline
\end{tabular}


Kostholdet ble kartlagt med et spørreskjema med spørsmål om hvor mye og hvor ofte deltakerne spiste av 180 matvarer, matretter og grupper av matvarer. Spørreskjemaet er evaluert mot veid registrering av kostholdet i 14 dager blant 38 eldre kvinner ${ }^{13}$, 48timers recall blant 123 dermatologiske pasienter ${ }^{14}$, veid registrering i 14 dager og konsentrasjonen av $\alpha$ tokoferol og fettsyrer i fettvev og serum blant 125 menn ${ }^{24}$, og mot konsentrasjonen av n-3 fettsyrer $\mathrm{i}$ plasmafosfolipider blant 579 menn og kvinner ${ }^{25}$. Evalueringsstudiene viste at skjemaet måler inntaket av energi og næringsstoffer på en akseptabel måte, sammenlignet med andre undersøkelsesmetoder. Ytterligere informasjon om representativitet, metode og resultater fra de to undersøkelsene er publisert tidlige$\mathrm{re}^{26-28}$. I forbindelse med planleggingen av Norkostundersøkelsen i 1992 testet man hvordan ulike distribusjonsmåter og belønning påvirket hvor mange som besvarte Norkostskjemaet. Bruk av belønning økte deltakerandelen betraktelig ${ }^{16}$.

I 1998-99 ble kostholdet til landsrepresentative utvalg av 3000 spedbarn undersøkt med hjelp av spørreskjema ved 6 og 12 måneders alder (Spedkost). Dessuten ble 3000 toåringer undersøkt i 1999 (Småbarnskost). (Lande m.fl., dette temanummeret)

SEF har også utviklet et kort spørreskjema som omfatter 32 matvarer eller grupper av matvarer som er brukt $\mathrm{i}$ en valideringsstudie og i fylkesundersøkelsen $\mathrm{i}$ Agder 1996. Data fra de to studiene er ikke publisert. SEF gjør også undersøkelser i tilknytning til planlegging og evaluering av tiltak, for eksempel skolemåltidet og kampanjene for å øke folatinntaket blant gravide. SEF planlegger å delta i undersøkelser av innvandreres kosthold i tilknytning til helseundersøkelsen i bydeler og regioner i Oslo 2000. Videre planlegger man innsamling av data som kan beskrive utviklingen av fysisk aktivitet og fysisk form $\mathrm{i}$ befolkningen.

Data samlet inn i overvåkingssystemet er brukt i en rekke stortingsmeldinger og rapporter, for eksempel Folkehelserapportene 1996 og 1999. De er også brukt i forbindelse med flere nordiske ${ }^{29}$ og europeiske samarbeidsprosjekter ${ }^{30}$, i over tyve vitenskaplige artikler siden 1997, og hittil i to doktorgradsavhandlinger ${ }^{31,32}$. Utvalgte data vil også bli brukt i det nasjonale helseindikatorsystemet som Folkehelsa nå utvikler.

Arbeidet med å dokumentere forandringer i matvareutvalg og matvarenes sammensetning pågår kontinuerlig. Næringsberegninger på grunnlag av matmengder ifølge matforsyningsstatistikk, forbruksundersøkelser og kostholdsundersøkelser utføres av IE. Man bør være oppmerksom på at man ved overgang til å bruke en ny matvaretabell i næringsberegningene kan innføre brudd i serien for næringsberegningene. Fra 1995 er beregningene av innhold av energi og næringsstoffer basert på «Den store matvaretabellen 1995», utgitt av Statens ernæringsråd og Statens næringsmiddeltilsyn. De viktigste forskjellene fra tidli- gere tabell er at fra 1995 er kostfiber ikke inkludert i karbohydrat. Energiinnholdet for kostfiber ble satt til null fra 1995, mens det i tabellen fra 1991 var regnet med $17 \mathrm{~kJ} / \mathrm{g}$ kostfiber. Energimengden som frigjøres ved forbrenning av ett gram fett er satt til $37 \mathrm{~kJ}$, i stedet for $38 \mathrm{~kJ}$ som ble brukt før 1995. Dette har blant annet ført til lavere totalt energiinnhold f.o.m. 1995, sammenlignet med tidligere år. Videre har man inkludert inntak av fisk ifølge GfK Norges husholdningspanel i næringsberegningen på grunnlag av matforsyningsstatistikken ${ }^{10}$.

\section{UTVIKLINGEN I NORSK KOSTHOLD}

Forbruket av ulike matvarer forandrer seg som regel sakte når en ser på hele befolkningen, men kan over tid forandre seg betydelig. Ettersom vi har årlige data fra matforsyningsstatistikken og forbruksundersøkelser i privathusholdninger fra henholdsvis 1953/55 og 1975 egner de seg til å beskrive utviklingen i matvareforbruket over $\operatorname{tid}^{10}$. Da de nasjonale kostholdsundersøkelsene bare er gjort siden 1993, er de foreløpig først og fremst brukt til å beskrive forskjeller i inntaket blant grupper av befolkningen ${ }^{22,23,33}$.

Matmengden (pr. person) som registreres i matforsyningsstatistikken skal være høyere enn tilsvarende tall i Forbruksundersøkelsene, bl.a. på grunn av svinn i matvarekjeden (figur 1). Ulike råvarer blir som regel i alt større grad kombinert $i$ halv- og helfabrikata når en går fra matforsyningsstatistikk til kostholdsundersøkelser. Det har derfor ingen hensikt å sammenligne enkelttall fra de to datasettene, eller å sammenligne disse med kostholdsundersøkelsene. Men sammen kan de tre datasettene gi et mer nyansert bilde av utviklingen av kostholdet enn hver for seg.

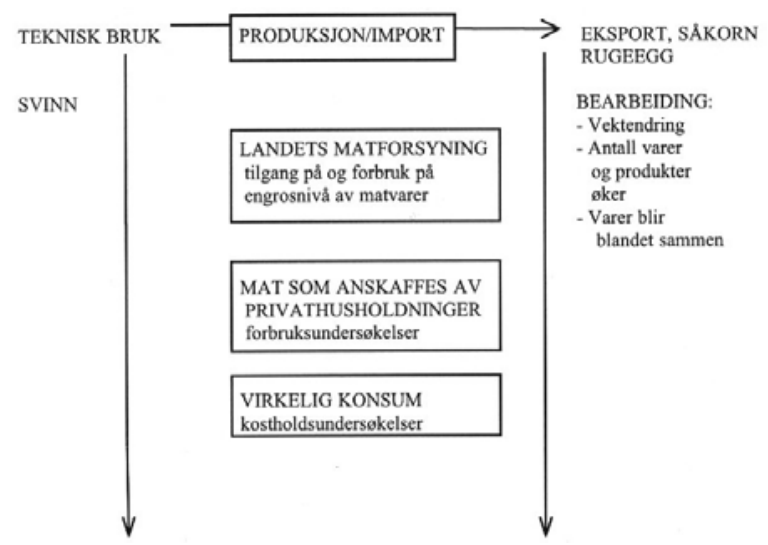

Figur 1. Matvarenes vei fra produksjon til konsum og hovedkilder til data om norsk kosthold.

Matvareforbruk og beregnet næringsinnhold ifølge de tre datanivåene $\mathrm{i}$ den samme tidsperioden er vist $\mathrm{i}$ tabell 3 og 4 . Data er hentet fra de to nasjonale kostholdsundersøkelsene blant menn og kvinner i alderen 
16-79 år i 1993-94 og i 1997 (Norkost), fra SSBs forbruksundersøkelser over anskaffelse av matvarer $i$ privathusholdinger i perioden 1992-94 og 1997, og fra matforsyningsstatistikk for hele landet i 1993 og 1997.

Opplysningene $\mathrm{i}$ tabell 3 og 4 gir $\mathrm{i}$ et lengre utviklingsperspektiv et "øyeblikksbilde" av kostholdet i løpet av noen få år i 1990-årene. I følgende avsnitt blir opplysningene i tabell 3 og 4 vurdert i forhold til forbrukstrender ifølge matforsyningsstatistikk og forbruksundersøkelser siden 1975. Ytterligere opplysninger er å finne i rapportene om utviklingen i norsk kosthold $^{10}$

\section{MATVAREFORBRUK}

Kornforbruket økte fra 75 til $84 \mathrm{~kg}$ /innbygger i perioden 1975-98 ifølge matforsyningsstatistikken. Det samlede engrosforbruket av hvete, rug og havre økte med 6,1 kg/innbygger, mens forbruket av ris økte med $3,4 \mathrm{~kg} /$ innbygger i denne perioden. Forbruket av kornvarer har imidlertid ikke økt ifølge forbruksundersøkelsene 1975-97 og de nasjonale kostholdsundersøkelsene i 1993-94 og 1997.

Forbruket av friske matpoteter er halvert siden begynnelsen av 1970-årene, mens forbruket av poteter til

Tabell 3. Matvareforbruk ifølge Matforsyningsstatistikk 1993 og 1997, Forbruksundersøkelser i privathusholdninger $1992-94$ og 1997, og Norkost 1993-94 og 1997, spiselig mengde gram pr. person pr. dag gjennomsnitt. ${ }^{a}$

\begin{tabular}{|c|c|c|c|c|c|c|}
\hline & \multicolumn{2}{|c|}{ Matforsyning } & \multicolumn{2}{|c|}{ Forbruksundersøkelser } & \multicolumn{2}{|c|}{ Norkost } \\
\hline & 1993 & 1997 & $\begin{array}{c}1992-94 \\
(\mathrm{n}=4033)\end{array}$ & $\begin{array}{c}1997 \\
(n=1260)\end{array}$ & $\begin{array}{c}1993-94 \\
(n=3144)\end{array}$ & $\begin{array}{c}1997 \\
(n=2672)\end{array}$ \\
\hline Kornvarer & 226 & 228 & 162 & 157 & 243 & 240 \\
\hline Kaker & & & 14 & 16 & 32 & 31 \\
\hline Poteter & 104 & 90 & 100 & 84 & 128 & 115 \\
\hline Potetprodukter & $52^{\mathrm{b}}$ & $55^{\mathrm{b}}$ & 10 & 12 & 6 & 8 \\
\hline Grønnsaker & 145 & 153 & 95 & 99 & 130 & 135 \\
\hline Frukt og bær & 193 & 171 & 183 & 187 & 214 & 222 \\
\hline - frisk frukt og bær & & & 105 & 105 & 113 & 118 \\
\hline - juice/most & & & 41 & 46 & 68 & 74 \\
\hline - konservert, syltetøy & & & 31 & 28 & 29 & 30 \\
\hline Kjøtt og kjøttprodukter & 132 & 142 & 116 & 116 & 109 & 106 \\
\hline Fisk og fiskprodukter & & $48^{\mathrm{c}}$ & 40 & 37 & 67 & 65 \\
\hline Egg & 27 & 25 & 19 & 18 & 18 & 17 \\
\hline Melk, totalt & 535 & 486 & 347 & 296 & 462 & 438 \\
\hline - Helmelk & 167 & 142 & 110 & 92 & 74 & 58 \\
\hline - Lettmelk & 232 & 218 & 173 & 156 & 267 & 251 \\
\hline - Skummetmelk & 136 & 126 & 64 & 48 & 121 & 101 \\
\hline Fløte, rømme & 22 & 19 & 12 & 11 & 10 & 9 \\
\hline $\begin{array}{l}\text { Yoghurt, iskrem, melke- } \\
\text { og fløteprodukter }\end{array}$ & & & 31 & 35 & 46 & 43 \\
\hline Ost & 38 & 40 & 29 & 29 & 32 & 31 \\
\hline Spisefett, totalt & 55 & 53 & 37 & 35 & 35 & 34 \\
\hline - margarin, myk & 12 & 10 & 12 & 10 & 5 & 7 \\
\hline - margarin, lett & 7 & 7 & 5 & 5 & 6 & 7 \\
\hline - margarin, annen & 19 & 18 & 13 & 11 & 7 & 6 \\
\hline - smør & 6 & 7 & 4 & 3 & 3 & 3 \\
\hline - annet spisefett & 11 & 11 & 10 & 11 & 12 & 12 \\
\hline Sukker, honning o.l. & 117 & 131 & 33 & 29 & 8 & 7 \\
\hline Søtsaker & & & 19 & 20 & 10 & 11 \\
\hline Brus, totalt & & & 166 & 199 & 198 & 218 \\
\hline - sukkersøtet & & & & & 122 & 151 \\
\hline - kunstig søtet & & & & & 76 & 67 \\
\hline$\varnothing 1$, vin, brennevin, totalt & & & 71 & 69 & 94 & 108 \\
\hline$-\varnothing 1$ & $168^{\mathrm{d}}$ & $184^{\mathrm{d}}$ & & & 77 & 86 \\
\hline - vin & 21 & 30 & & & 13 & 17 \\
\hline - brennevin & 7 & 7 & & & 4 & 4 \\
\hline
\end{tabular}

${ }^{a}$ Matvarene er ikke gruppert på samme måte som i tidligere tabeller.

b Potetprodukter er omregnet til friske poteter i Matforsyningsstatistikken.

${ }^{\mathrm{c}}$ Produktvekt av fisk anskaffet i privathusholdninger ifølge GfK Norges husholdningspanel, Eksportutvalget for fisk.

${ }^{\mathrm{d}}$ Registrert forbruk pr. innbygger 15 år og over, vareliter, Statistisk sentralbyrå. 
Tabell 4. Kostens innhold av næringsstoffer ifølge Matforsyningsstatistikk 1993 og 1997, Forbruksundersøkelser i privathusholdninger 1992-94 og 1997, og Norkost 1993-94 og 1997, mengde pr. person pr. dag gjennomsnitt.

\begin{tabular}{|c|c|c|c|c|c|c|}
\hline & \multicolumn{2}{|c|}{ Matforsyning } & \multicolumn{2}{|c|}{ Forbruksundersøkelser } & \multicolumn{2}{|c|}{ Norkost } \\
\hline & 1993 & 1997 & $\begin{array}{c}1992-94 \\
(\mathrm{n}=4033)\end{array}$ & $\begin{array}{c}1997 \\
(\mathrm{n}=1260)\end{array}$ & $\begin{array}{c}1993-94 \\
(\mathrm{n}=3144)\end{array}$ & $\begin{array}{c}1997 \\
(\mathrm{n}=2672)\end{array}$ \\
\hline Energi (MJ) & 12,6 & 12,3 & 9,9 & 9,2 & 9,5 & 9,4 \\
\hline Protein $(g)$ & 95 & 93 & 76 & 73 & 88 & 86 \\
\hline Fett $(g)$ & 113 & 113 & 90 & 86 & 80 & 79 \\
\hline Karbohydrat (g) & 392 & 383 & 296 & 274 & 288 & 284 \\
\hline Sukker $(\mathrm{g})$ & 122 & 135 & 81 & 78 & 55 & 56 \\
\hline Alkohol (g) & & & 4 & 4 & 5 & 6 \\
\hline Kostfiber (g) & 22 & 23 & 16 & 17 & 23 & 23 \\
\hline Kolesterol (mg) & & & 290 & 280 & 301 & 291 \\
\hline Retinolekvivalenter (mg) & & & 1,3 & 1,2 & 1,6 & 1,5 \\
\hline Vitamin D $(\mu \mathrm{g})$ & & & 4,5 & 4,5 & 5,0 & 4,8 \\
\hline Tiamin (mg) & & & 1,3 & 1,3 & 1,5 & 1,4 \\
\hline Riboflavin (mg) & & & 1,5 & 1,4 & 1,9 & 1,7 \\
\hline Vitamin C (mg) & & & 75 & 88 & 116 & 120 \\
\hline Kalsium (g) & & & 0,8 & 0,8 & 1,0 & 0,9 \\
\hline Jern (mg) & & & 10 & 9,5 & 11 & 11 \\
\hline \multicolumn{7}{|c|}{ Andel av energiinntak (\%) } \\
\hline Protein & 13 & 13 & 13 & 14 & 16 & 16 \\
\hline Fett & 34 & 34 & 35 & 34 & 31 & 31 \\
\hline - mettede fettsyrer & 14 & 14 & 14 & 13 & 12 & 12 \\
\hline - enumettede fettsyrer & 12 & 12 & 12 & 12 & 11 & 11 \\
\hline - flerumettede fettsyrer & 5 & 5 & 6 & 6 & 5 & 5 \\
\hline Karbohydrat & 53 & 52 & 51 & 51 & 52 & 52 \\
\hline Sukker & 17 & 19 & 14 & 14 & 9 & 9 \\
\hline Alkohol & & & 1 & 1 & 2 & 2 \\
\hline
\end{tabular}

potetprodukter som pommes frites og chips, nå utgjør $41 \%$ av den totale potetomsetningen på engrosnivå, mot ca. $10 \%$ i 1975 . Forbruksundersøkelsene og Norkost-undersøkelsene viser samme trend.

I perioden 1975-98 økte engrosforbruket av grønnsaker fra 37 til $60 \mathrm{~kg} /$ innbygger, mens engrosforbruket av frukt og bær forandret seg lite og var $74 \mathrm{~kg} /$ innbygger både i 1975 og 1998. En må imidlertid være oppmerksom på at matforsyningsstatistikken for grønnsaker, frukt og bær er blitt mer usikker de senere år. I følge forbruksundersøkelsene økte forbruket av grønnsaker og frukt og bær med henholdsvis $25 \%$ og $30 \%$ i perioden 1975-97. I hele denne perioden var imidlertid forbruket av frisk frukt uforandret, mens forbruket av juice og most økte flerfoldig. Inntaket av grønnsaker og frukt var noe høyere i Norkost 1997 sammenlignet med Norkost 1993-94. Ifølge Norkost-undersøkelsene var det gjennomsnittlige inntaket av poteter, grønnsaker, frukt og bær ca. $480 \mathrm{~g}$ pr. dag tilsvarende 3,1 porsjoner pr. dag i 1993-94 og 3,2 porsjoner pr. dag i 1997. Bare ca. $10 \%$ hadde en brukshyppighet på 5 ganger eller mer pr. dag.
Kjøttforbruket økte fra 52 til $64 \mathrm{~kg} /$ innbygger på engrosnivå i perioden 1975-98. Hittil i 1990-årene har det økt med drøyt $10 \mathrm{~kg}$ pr. person, og det har aldri vært registrert et så høyt engrosforbruk av kjøtt i Norge som i 1998. Ifølge forbruksundersøkelsene har imidlertid den totale kjøttmengden som er anskaffet av privathusholdninger forandret seg lite de siste femten årene. Dessuten var inntaket av kjøtt lavere i Norkost 1997 enn i Norkost 1993-94.

Datagrunnlaget for forbruk av fisk er usikkert både på engrosnivå og i forbruksundersøkelsene. Derfor er det siden 1995 gjennomført undersøkelser for å få tall på anskaffelsen av fisk og fiskevarer i privathusholdninger. Anskaffelsen av fisk og fiskevarer økte noe fra 1995 til 1998 ifølge GfK Norges husholdningspanel. Omregnet til filet tilsvarte forbruket $10,7 \mathrm{~kg}$ per person i 1995 og 11,3 kg i 1998, mens de tilsvarende tall for hel urenset fisk (rund vekt) var henholdsvis $27,9 \mathrm{~kg}$ og $29,7 \mathrm{~kg}$. Både forbruksundersøkelsene og Norkostundersøkelsene tyder imidlertid på en nedgang i forbruket av fisk i 1990-årene.

Eggforbruket økte på engrosnivå fram til midten av 
1980-årene, men har siden minsket både ifølge matforsyningsstatistikk og forbruksundersøkelser. Norkostundersøkelsene viser også en nedgang i eggforbruket.

Engrosforbruket av konsummelk (søt og sur helmelk, lettmelk og skummetmelk) har minsket siden slutten av 1970-årene, mens forbruket av konserverte melkeprodukter (tørrmelk o.l.) økte fram til midten av 1990-årene. Det samlede engrosforbruket av konsummelk og konserverte melkeprodukter var i 1979, 1989 og 1998 henholdsvis 201, 202 og 175 liter/person/ år. Lettmelk har utgjort halvdelen av drikkemelken siden 1990. Forbruket av helmelk er minsket til en fjerdedel av forbruket i slutten av 1970-årene. Samtidig har skummetmelk beholdt sin markedsandel.

Osteforbruket økte fra 10 til $15 \mathrm{~kg} /$ innbygger på engrosnivå i perioden 1975-98. Det er forbruket av hvit ost som har økt, forbruket av brun ost har minsket. Forbruket av fløte har vært forholdsvis stabilt de siste tretti årene, mens forbruket av smør har minsket jevnlig i flere tiår og er halvert siden 1979. Tallene fra forbruksundersøkelsene og Norkostundersøkelsene i 1993-94 og 1997 viser samme trender i forbruket av konsummelk, fløte og smør som engrosstatistikken. De viser imidlertid ikke den samme stigningen i forbruk av ost.

Engrosforbruket av margarin gikk ned fram til 1989, og forandret seg deretter lite fram til 1996. Forbruket minsket imidlertid med $1 \mathrm{~kg}$ pr. innbygger i 1997 og holdt seg på dette nivået også i 1998. Andelen av myk margarin har økt jevnlig siden 1970-årene og utgjør nå $56 \%$ av margarinforbruket på engrosnivå. Økningen i forbruk av lett margarin har stoppet opp i de senere år. Forbruksundersøkelsene viser de samme trendene som matforsyningsstatistikken både for totalt forbruk og valg av type margarin. Dessuten viser de at forbruket av matolje og matvarer som inneholder olje som dressing og majonessalater ble doblet siden 1980 . Det var imidlertid liten forskjell i gjennomsnittlig inntak av ulike typer spisefett mellom Norkost 1993-94 og 1997.

Sukkerforbruket på engrosnivå har stort sett svingt mellom 40 og $45 \mathrm{~kg}$ de siste 40 årene med uvanlig lave tall i 1975 og uvanlig høye tall i 1997. Svingningene fra år til år kan skyldes ujevn prisutvikling med tilhørende hamstring $\mathrm{i}$ tider med forventede prisoppganger. Fordi det ikke finnes sikre data for lagerendringer av sukker, og bruk av sukker til teknisk bruk og fôr, er det vanskelig å beregne engrosforbruket nøyaktig. Engrosforbruket er imidlertid vesentlig høyere enn det sukkerforbruket som er registrert i forbruksundersøkelsene og i kostholdsundersøkelser. For eksempel var det gjennomsnittlige sukkerforbruket henholdsvis 56, 78 og 124 g/person/dag ifølge Norkost 1997, forbruksundersøkelsene 1997 og matforsyningsstatistikken 1998. Det reelle sukkerinntaket er sannsynlig lavere enn hva matforsyningsstatistikken viser fordi sukker blir brukt til annet enn mat.

I løpet av de siste tyve årene har andelen av kostens energiinnhold som kommer fra sukker ligget rundt 8$10 \%$ blant voksne og 10-16\% blant tenåringer ifølge kostholdsundersøkelser, $13-15 \%$ ifølge forbruksundersøkelser og 15-19\% ifølge matforsyningsstatistikk. Matforsyningsstatistikken tyder på en økning i det samlede sukkerforbruket de siste tyve årene, mens forbruksundersøkelsene ikke viser noen økning. Norkostundersøkelsene 1993-94 og 1997 tyder heller ikke på en økning. Måten man bruker sukker på er forandret. Forbruket av rent sukker er nesten halvert, samtidig som det har vært en betydelig økning i forbruket av godterier og brus. Det samlede mineralvannforbruket er doblet siden 1980. Omsetningen av sukkerholdig brus var på sitt høyeste, 91 liter pr. innbygger, i 1997 for siden å minske noe til 88 liter i 1998. De siste årene har andelen kunstig søtet brus av total mineralvannomsetning minsket. Av det totale sukkerforbruket på engrosbasis gir søtet brusdrikk nå gjennomsnittlig ca. $9 \mathrm{~kg}$ sukker pr. person $\mathrm{i}$ året.

Det registrerte alkoholforbruket økte fra 2,9 til 6 liter ren alkohol pr. innbygger fra 15 år og over $i$ perioden 1950 til 1980, for siden å synke til 5 liter i 1990. Fra 1994 har det økt noe igjen. Økningen i alkoholinntak de siste tiårene skyldes høyere forbruk av vin og øl. Totalomsetningen av alkoholholdige drikker var vesentlig høyere enn det som ble registrert i forbruksundersøkelsene og Norkost-undersøkelsene. Norkost-undersøkelsene viste imidlertid de samme trendene som omsetningsstatistikken med økt bruk av øl og vin, og uforandret bruk av brennevin.

\section{ENERGI OG N/ERINGSSTOFFER}

Norsk gjennomsnittskost inneholder tilfredsstillende mengder av de fleste livsnødvendige næringsstoffer $i$ forhold til anbefalt inntak, med unntak for vitamin D, samt jern og folat blant kvinner i barnefødende aldre. Det finnes imidlertid fortsatt klare helsemessige svakheter ved kostholdet. Særlig inneholder det for mye mettet fett og for lite av matvarer rike på kostfiber som poteter, grønnsaker, frukt og grove kornprodukter.

Når man sammenligner de tre datasettene var kostens energiinnhold ca. $30 \%$ høyere på engrosnivå sammenlignet med to andre datasettene (tabell 4). Alle datasettene viser små endringer i fordelingen av energiinntaket på de energigivende næringsstoffene fett, protein og karbohydrat i perioden 1993-97.

Sett i forhold til dagens helseproblemer, er det spesielt viktig å følge utviklingen av kostens fettinnhold, både med hensyn til totalt fettinnhold og fett-type. Fra 1975 til 1990 minsket kostens fettinnhold fra 40 til 35 prosent av kostens energiinnhold (E\%) og har siden holdt seg på dette nivået ifølge både matforsyningsstatistikk og forbruksundersøkelser. I de nasjonale kostholdsundersøkelsene fra 1993-94 og 1997 var det gjennomsnittlige fettinntaket ca. 30 energiprosent både blant skoleelever og voksne. 
Kostens fettsyresammensetning har endret seg i ønskelig retning, og kolesterolinnholdet er redusert siden 1970-årene. Det anbefales at høyst 10 energiprosent bør komme fra hardt fett (mettede fettsyrer + transfettsyrer). Kosten innhold av mettede fettsyrer har minsket fra ca. 17 til 14 energiprosent siden 1975 både på engrosnivå og $\mathrm{i}$ forbruksundersøkelsene.

Transfettsyrer dannes både ved industriell herding av plante- og fiskeoljer, og i vommen til drøvtyggere under fordøyelsesprosessen. De matvaregruppene som tradisjonelt har inneholdt vesentlige mengder av transfettsyrer er derfor margarin, meieri- og kjøttvarer. Hard margarin, og særlig de margarintypene som var basert på partielt herdet fiskeolje, hadde det høyeste innholdet av både transfettsyrer og mettede fettsyrer. Margarinens sammensetning er imidlertid betydelig endret i løpet av de senere år. I begynnelsen av 1990årene var det estimert at kosten inneholdt 2-3 energiprosent transfettsyrer. På grunnlag av Norkostundersøkelsen 1993-94 ble det beregnet at mettede fettsyrer i gjennomsnitt utgjorde 12,5 energiprosent og transfettsyrer 1,5 energiprosent, når man brukte nye matvareanalyser fra 1996. Nå inneholder bordmargarin ikke lenger transfettsyrer. Ut fra et helsemessig perspektiv representerer derfor de mettede fettsyrene i dag det største problemet.

Nedgangen i kostens fettinnhold er først og fremst et resultat av et redusert margarinforbruk i en lengre tidsperiode, redusert forbruk av smør de siste årene, og overgang til magrere melketyper og lettmargarin. I 1990-årene er nedgangen i kostens fettinnhold fra disse kildene til dels oppveid ved en økt fettilførsel fra ost, kjøtt og gruppen «andre matvarer» som bl.a. omfatter kaker, snacks og godteri. To tredjedeler av de mettede fettsyrene kommer fra meieri- og kjøttprodukter. For å redusere det totale inntaket av mettede fettsyrer er det derfor særlig viktig å minske inntaket av smør og hard margarin, samt å bytte fra fete til magre varianter av meieri- og kjøttvarer.

Andelen karbohydrat i kosten økte fra 1975 til begynnelsen av 1990-årene og har siden forandret seg lite. Den begrensende økningen av stivelse henger sammen med at det har vært en begrenset endring $i$ kornforbruket og at potetforbruket har minsket. Kostens sukkerinnhold er vesentlig høyere enn 10 energiprosent både på engrosnivå og i forbruksundersøkelsene. I de nasjonale kostholdsundersøkelsene utgjorde sukkerinntaket 11-13 energiprosent blant grupper av skoleelever og 9 energiprosent blant voksne. Kostens fiberinnhold har forandret seg lite de siste 10 år, og er fortsatt vesentlig lavere enn ønskelig.

\section{DISKUSJON}

\section{Datakvalitet}

De tre typene datasett som i denne artikkelen er brukt til å beskrive norsk kosthold belyser kostholdet på forskjellig måte. De kan derfor komplettere hverandre, men alle tre datasettene har sine metodiske svakheter.

Matforsyningsstatistikken gir et grovt mål på den mengden matvarer som står til rådighet for hele befolkningen på engrosnivå ${ }^{34}$. Matforsyningsstatistikken for de ulike matvaregruppene er ikke like sikker. For fisk er engrosstatistikken så usikker at man ikke ønsker å bruke den.

Sammenligningene mellom de tre tallsettene viste forskjeller i utviklingstrender for forbruket av noen matvaregrupper, for eksempel kjøtt og sukker. Hva som er årsaken til dette vet vi foreløpig ikke. En viktig forskjell mellom matforsyningsstatistikk og forbruksundersøkelser er at varer som går til storhusholdninger ikke er inkludert i tallene fra forbruksundersøkelsene. Det er tidligere gjort forsøk på å finne forklaringer på de store forskjellene i sukkerforbruk mellom de tre datanivåene $^{35}$, og NILF vurderer muligheter for supplering av statistikken for engrosforbruk av sukker ${ }^{36}$.

Det var også forskjell i hvor stor andel av kostens energiinnhold som kom fra fett mellom Norkostundersøkelsene (31 E\%) og de andre to datanivåene (34-35 E\%). Den viktigste årsaken er trolig forskjellene i metode for å registrere forbruket. Det lavere nivået i Norkostundersøkelsene kan imidlertid også komme av en overrepresentasjon av personer med sunne matvarevalg blant deltakerne. Sammen tyder de tre datasettene på at kostens fettinnhold ligger mellom 30 og $35 \mathrm{E} \%$.

Forbruksundersøkelsene viser anskaffelsen av mat i privathusholdninger, men de viser ikke den mengde mat som blir kjøpt og spist utenfor husholdningen ${ }^{10}$. Andelen av utgiftene til slikt konsum har økt betydelig over tid, og denne andelen er trolig forskjellig i ulike grupper av befolkningen. I 1983-85 og 1997 var utgiftene til konsum av mat og drikke utenfor hjemmet henholdsvis $2,6 \%$ og 3,7\%. Samtidig minsket andelen av utgiftene til mat og drikkevarer av total forbruksutgift fra $21 \%$ til $15 \%$. Et annet forhold som bør tas hensyn til ved sammenligning av data over tid er omregningen fra forbruk på husholdningsnivå til forbruk per person. Dette gjøres ved å dele forbruket på antall husholdningsmedlemmer uten å ta hensyn til husholdningens alderssammensetning. I perioden 1975-97 har antallet personer i gjennomsnittshusholdningen minsket fra 2,79 til 2,26 personer/husholdning. Et stort problem med forbruksundersøkelsene er at andelen deltakere har minsket fra 68\% til 58\% i perioden 1975-1997.

Det finnes en rekke metoder som kan brukes ved kostholdsundersøkelser blant grupper av individer. Alle metodene har sine svakheter, og det finnes ikke noen ideell metode ${ }^{15,37}$. Det selvadministrerte og maskinlesbare spørreskjemaet som ble brukt i Norkostundersøkelsene har sine sterke og svake sider ${ }^{32}$. Distribusjon og databehandling var relativt enkel, og kostnadene for datainnsamlingen var relativt lav (ca. kr 500.000.- for drøyt 3000 personer i 1994). Skjemaet skal måle kostholdet slik det vanligvis har vært for den 
enkelte det siste året. Dette er en fordel sammenlignet med metoder som bare måler kostholdet en eller ett par dager, for eksempler 24-h recall og en dags registrering. Skjemaet skiller imidlertid ikke på hverdag og helg, og forutsetter at de som svarer kan angi et gjennomsnitt for matinntaket over en lengre tid. Dessuten er det omfattende, 11 sider, og kan skape problemer for de med lesevansker.

Utformingen av spørreskjemaet minsker variabiliteten i rapportert matinntak sammenlignet med reelt inntak. F.eks. har spørreskjemaet faste svaralternativ for matvarene som konsumeres. Dessuten er det ikke spurt om adferd som kan påvirke næringsinnholdet på de matvarene som konsumeres. F.eks. om man fjerner synlig fett, en vane som er vanligere blant kvinner enn menn (48 vs. $34 \%$ ), og blant de med teoretisk mot de med praktisk utdanning (53 vs. 29\%) ) $^{39}$. Mangel på slik informasjon kan minske variansen mellom personer og gjøre det vanskeligere å finne forskjeller mellom grupper.

Videre legges det i spørreskjemaet vekt på å måle inntaket av matvarer som var av stor betydning i et vanlig norsk kosthold ut fra kunnskaper fra tidligere kostholdsundersøkelser. Det egner seg derfor ikke til å samle informasjon om varer som er sjeldent brukt $i$ befolkningen eller å måle inntaket blant personer som har et kosthold som avviker mye fra tradisjonelt norsk kosthold. Ettersom vi kan forvente at matvaretilbudet og matvanene vil endres over tid kan bruken av faste svaralternativer skape et problem. Derfor bør data innsamlet med denne typen spørreskjema over tid kompletteres med opplysninger fra undersøkelser som bruker åpne svaralternativer.

Metodeevalueringene viste at reproduserbarheten av svarene på spørreskjemaet var på nivå eller bedre enn for de fleste andre tilsvarende spørreskjema ${ }^{16}$, og at det målte inntaket av energi og næringsstoffer på en akseptabel måte ${ }^{13,14,24,25}$. Andelen deltakere som oppga usannsynlig lave energiinntak i Norkost ${ }^{39}$, var i samme størrelsesorden (40-50\%) som i nasjonale kostholdsundersøkelser i Storbritannia $^{40}$, USA $^{41}$ og Finland ${ }^{42}$. Vekthøydeindeks og holdninger til egen kroppsvekt var sterkt assosiert med under- eller overrapportering av energiinntaket ${ }^{39}$. Dette er forhold som det i større grad bør tas hensyn til ved vurdering av sammenhenger mellom inntak og helseforhold ${ }^{43}$.

Et stort problem i forbindelse med undersøkelser blant representative utvalg av befolkningen er å sikre en høy deltakerandel, samt å unngå skjevheter i sammensetningen blant de som deltar. I pilotundersøkelsen som ble gjort i forkant av Norkostundersøkelsene fant man at postal distribusjon av spørreskjema kombinert med innsamling via intervjuer i SSBs Omnibus, og mulighet til å delta i en utlodning av gavekort, ga den høyeste svarprosenten på $72 \%$. Når samme innsamlingsmetode kombinert med belønning ble brukt $\mathrm{i}$ de to Norkostundersøkelsene 1993-94 og 1997 minsket deltakerandelen til henholdsvis $63 \%$ og $54 \%$. I fem nasjo- nale undersøkelser i de nordiske land 1985-95 varierte deltakerandelen fra $56 \%$ til $76 \%{ }^{44-48}$. I de danske nasjonale kostholdsundersøkelsene minsket deltakerandelen fra $76 \%$ i 1985 til 56\% i 1995. Deltakerandelen i Statens helseundersøkelsers fylkesundersøkelser var ca. 90\% i 1970-årene ${ }^{49}$, og har i 1990-årene holdt seg mellom 52\% og 75\%, med det laveste nivået i AustAgder $1998^{50}$. Det bør derfor legges et betydelig arbeid på å opprettholde en høy deltakerandel i kommende undersøkelser.

\section{Overvåking av kostholdet - nasjonalt og internasjonalt}

De fleste industriland samler data som kan beskrive kostholdet $^{51,52}$. Hvilke metoder og hvor mye ressurser som blir brukt varierer mye. De fleste samler matforsyningsstatistikk og gjennomfører forbruksundersøkelser. Men det er ikke så mange land som gjennomfører nasjonale kostholdsundersøkelser som en del av et overvåkingssystem. I begynnelsen av 1990-årene hadde følgende land gjennomført nasjonale kostholdsundersøkelser: Australia, Canada, USA, Belgia, Danmark, Finland, Tyskland, Island, Irland, Nederland, Portugal, Sverige og Storbritannia ${ }^{52}$. I flere av disse nasjonale undersøkelsene samlet man inn data både om kosthold og kostrelaterte helseforhold. På tross av at flere av de nasjonale undersøkelsene var planlagt å gjentas, så var flerparten av dem bare gjort en gang. De nasjonale undersøkelsene har vært forskjellige både når det gjelder metode og utvalg av befolkningen. Deltakerandelen har variert fra $37 \%$ i Belgia til $81 \%$ i Nederland ${ }^{52}$

USA har lange tradisjoner når det gjelder overvåking av kostholdet og det amerikanske systemet for datainnsamling er trolig det mest omfattende ${ }^{53,54}$. For eksempel brukte den tredje National Health and Nutrition Examination Survey (NHANES III) 24-timers recall på et representativt utvalg av 40000 personer $\mathrm{i}$ løpet av en seks års periode (1988-94). Korte spørreskjema for telefonintervju om bruken av utvalgte matvarer blir brukt regelmessig i USA, og er nå også tatt i bruk i Danmark ${ }^{55}$.

Internasjonal matforsyningsstatistikk (Food Balance Sheets) fra ca. 200 land er publisert av Food and Agriculture Organization of the United Nations (FAO) siden 1949. Dessuten publiserer mange land nasjonal statistikk. For eksempel er det publisert matforsyningsstatistikk i USA siden 1909, i Nederland siden 1950 og Norge siden 1952. Nasjonale data kan være forskjellige fra den internasjonale statistikk både med hensyn til forbruk av matvarer og næringsstoffer ${ }^{34,56}$. Nordisk matforsyningsstatistikk er publisert i Nordisk statistisk årbok siden 1990. På tross av at de basale datakildene og beregningsmetodene er relativt likartede for hovedgruppene av matvarer i Norden, så medfører forskjeller i datakilder og omregningsfaktorer problemer når man skal sammenligne statistikken for flere matvare- 
grupper, særlig fisk og grønnsaker ${ }^{57}$.

Mange industriland startet med forbruksundersøkelser i 1940- og 1950-årene, men bare noen land har et system for regelmessige forbruksundersøkelser. I Storbritannia har man gjennomført The National Food Survey årlig i et halvt århundre ${ }^{58}$. I USA gjennomførte man den første forbruksundersøkelsen i 1936-37, og siden 1965 samler denne undersøkelsen også inn opplysninger om matinntaket til de enkelte medlemmene $i$ husholdningen ${ }^{59}$. Til sammenligning har man i Norge gjennomført årlige forbruksundersøkelser med registrering av matvareforbruket blant landsrepresentative utvalg av husholdninger siden 1975. Internasjonalt foreligger det derfor en rekke forbruksundersøkelser, men det er relativt store forskjeller på de metodene som er brukt. Norge deltar i europeiske samarbeidsprosjekt som bearbeider innsamlede data for å kunne gjøre internasjonale sammenligninger, samtidig som man forsøker få til en harmonisering av metodene $e^{8,60,61}$.

\section{KONKLUSJON}

Det norske overvåkingssystemet er forsatt i en utviklingsfase, og det må justeres og kompletteres etter hvert. Dessuten må det hele tiden arbeides med å kvalitetssikre datainnsamlingen. Ettersom matvaremarkedet og befolkningens matvaner er i konstant forandring må de metoder man bruker tilpasses utviklingen, samtidig som man må beholde mulighetene til å sammenligne med tidligere undersøkelser for å kunne beskrive utviklingen over tid. Det er også av stor interesse å få data som kan gjøre det mulig å sammenligne kostholdet mellom ulike land. Det har i flere tiår vært et nordisk samarbeid blant annet angående standardisering av matvaredatabaser, metoder for kostholdsundersøkelser, og forbedring av sammenlignbarheten av matforsyningsstatistikk. SEF deltar i flere europeiske samarbeidsprosjekt med formål å få bedre og sammenlignbare data om kostholdet.

\section{REFERANSER}

1. World Health Organization: Diet, nutrition, and the prevention of chronic diseases. Report of a WHO Study Group. Technical Report Series 797. WHO, Geneva, 1990.

2. St. meld. nr. 32 (1975-76). Om norsk ernærings- og matforsyningspolitikk. Landbruksdepartementet.

3. St. meld. nr. 11 (1981-82). Om oppfølging av norsk ernæringspolitikk. Sosialdepartementet.

4. St. meld. nr. 37 (1992-93). Utfordringer i helsefremmende og forebyggende arbeid. Sosial- og helsedepartementet.

5. Botten G. Overvåking av ernærings- og matsituasjonen i befolkningen. Forslag til et organisert opplegg. Utredning utført etter oppdrag fra Norges råd for anvendt samfunnsforskning (NORAS). Oslo, april 1988.

6. Botten G, Ørbeck Sørheim A, Johansson L og Larsen S. Konkretisering av et forslag om system for overvåking av mat og ernæringssituasjonen i Norge. Norges råd for anvendt samfunnsforskning (NORAS). Arbeidsnotat, Oslo, mai 1989.

7. Botten G, Johansson L, Haglerød A, Trygg K. System for fortløpende beskrivelse av ernæringssituasjonen i den norske befolkning. Notat fra en ad-hoc gruppe nedsatt av Statens ernæringsråd, Oslo, 1990.

8. Johansson L, Becker W, Groth M, Seppänen R. Overvåking av ernæringssituasjonen i Norden - Forprosjekt. Rapport til Nordisk arbeidsgruppe for kost og ernæringsspørsmål. Nordisk Ministerråd, Oslo, 1991.

9. Arbeidsgruppen for ernæring og matpolitikk. Konkurransestrategier for norsk mat. Beskrivelse av et overvåkingssystem for matvarer og kosthold i Norge. Notat, Oslo, mai 1993.

10. Statens råd for ernæring og fysisk aktivitet. Utviklingen i norsk kosthold. Rapport nr. 1 1999. Oslo, 1999.

11. Cameron ME, van Staveren WA (eds). Manual on methodology for food consumption studies. Oxford University Press, Oxford, 1988.

12. Thompson FE, Byers T. Dietary assessment resource manual. J Nutr 1994; 124 (Suppl 11): 2245S-2317S.

13. Nes M, Frost Andersen L, Solvoll K, et al. Accuracy of a quantitative food frequency questionnaire applied in elderly Norwegian women. Eur J Clin Nutr 1992; 42: 809-21.

14. Solvoll K, Lund-Larsen K, Søyland E, Sandstad B, Drevon CA. A quantitative food frequency questionnaire evaluated in a group of dermatologic outpatients. Scand J Nutr 1993; 37: 150-5.

15. Haraldsdottir J, Seppänen R, Løken E, et al. Kostholdsundersøkelser. Hvorfor og hvordan? PNUN rapport 1987:2. Nordisk ministerråd, København 1987.

16. Johansson L, Solvoll K, Opdahl S, Bjørneboe G-EAa, Drevon CA. Response rates with different distribution methods and reward, and reproducibility of a quantitative food frequency questionnaire. Eur J Clin Nutr 1997; 51: 346-53.

17. Andersen LF, Nes M, Sandstad B, Bjørneboe G-EAa, Drevon CA. Dietary intake among Norwegian adolescents. Eur J Clin Nutr 1995; 49: 555-64. 
18. Nicolaysen R, Eeg-Larsen N, Jervell A, Owren PA, Hjort PF, Øgrim ME, Gran FC. Report on the relation between fat and cardiovascular diseases (English summary). National Association for Public Health, Oslo, 1963.

19. Johansson L. Kostholdets betydning for dødeligheten av hjerteinfarkt i Norge de siste 100 år. Hovedfagsoppgave. Statens ernæringsråd og Avdeling for kostholdsforskning, Universitetet i Oslo, Oslo, 1993.

20. Statens ernæringsråd. UNGKOST-93. Rapport. Oslo, 1997.

21. Andersen LF, Nes M, Lillegaard IT, Sandstad B, Bjørneboe G-EAa, Drevon CA. Evaluation of a quantitative food frequency questionnaire used in a group of Norwegian adolescents. Eur J Clin Nutr 1995; 49: 543-54.

22. Norkost 1993-94. Landsomfattende kostholdsundersøkelse blant menn og kvinner i alderen 16-79 år. Rapport. Statens ernæringsråd, Oslo, 1997.

23. Johansson L, Solvoll K. Norkost 1997. Landsomfattende kostholdsundersøkelse blant menn og kvinner i alderen 16-79 år. Rapport. Statens ernæringsråd, Oslo, 1999.

24. Andersen LF, Solvoll K, Johansson LRK, Salminen I, Aro A, Drevon CA. Evaluation of a food frequency questionnaire with weighed records, fatty acids and alpha-tocopherol in adipose tissue and serum. Am J Epidemiol, accepted for publication.

25. Andersen LF, Solvoll K, Drevon CA. Very long-chain n-3 fatty acids as biomarkers for intake of fish and n-3 fatty acid concentrates. Am J Clin Nutr 1996; 64: 305-11.

26. Teigum HM. Kostholdsundersøkelsen 1997. Dokumentasjonsrapport. Notater 1998, Statistisk sentralbyrå, Oslo, 1998.

27. Johansson L, Solvoll K, Bjørneboe G-EAa, Drevon CA. Dietary habits among Norwegian men and women. Scand J Nutr 1997; 41: 63-70.

28. Johansson L, Thelle DS, Solvoll K, Bjørneboe G-EAa, Drevon CA. Healthy dietary habits in relation to social determinants and lifestyle factors. Brit J Nutr 1999; 81: 211-20.

29. Johansson L, Becker W, Fagt S, Thorgeirsdottir H, Valsta L. Grønnsak- og fruktinntaket i Norden. Scand $J$ Nutr 1999; 43: 8-12.

30. Hulshof KF, van Erp-Baart MA, Anttolainen M, et al. Intake of fatty acids in western Europe with emphasis on trans fatty acids: the TRANSFAIR Study. Eur J Clin Nutr 1999; 53: 143-57.

31. Andersen LF. Evaluation of food frequency questionnaires used among different groups of the Norwegian population. Thesis. Institute for Nutrition Research, University of Oslo, Oslo, 1998.

32. Johansson LRK. Norwegian dietary habits. Methods for nutritional surveillance. Thesis. Institute for Nutrition Research, University of Oslo. National Nutrition Council, Oslo, 1999.

33. Johansson L, Solvoll K. Norkost 1993-94 og 1997. Landsomfattende kostholdsundersøkelser blant menn og kvinner i alderen 16-79 år. Rapport. Statens ernæringsråd, Oslo, 1999.

34. Becker W, Helsing E (eds). Food and health data. Their use in nutrition policy-making. WHO Regional Publications European Series, No. 34. WHO, Copenhagen, 1991.

35. Lund-Larsen K, Rimestad AH. Distribusjonskjeden for sukker - eller sukkeret som forsvant. Näringsforskning 1985; 29: 113-6.

36. Berge S. Sukker. Muligheter for supplering av statistikken for engrosforbruket. Norsk institutt for landbruksøkonomisk forskning, Oslo, 1999.

37. Bingham SA, Gill C, Welch A, et al. Comparison of dietary assessment methods in nutritional epidemiology: weighed records v. $24 \mathrm{~h}$ recalls, food-frequency questionnaires and estimated-diet records. Br J Nutr 1994; 72: 619-43.

38. Spisevaner. Kombibuss mars 1984. Marketing Link a.s., Oslo, 1984.

39. Johansson L, Solvoll K, Bjørneboe G-EAa, Drevon CA. Under- and overreporting of energy intake related to weight status and lifestyle in a nationwide sample. Am J Clin Nutr 1998; 68: 266-74.

40. Gregory J, Foster K, Tyler H, Wiseman M. The dietary and nutritional survey of British adults. HMSO, London, 1990.

41. Klesges RC, Eck LH, Ray JW. Who underreports dietary intake in a dietary recall? Evidence from the Second National Health and Nutrition Examination Survey. J Consult Clin Psychol 1995; 63: 438-44.

42. Hirvonen T, Männistö S, Roos E, Pietinen P. Increasing prevalence of underreporting does not necessarily distort dietary surveys. Eur J Clin Nutr 1997; 51: 297-301.

43. Black AE, Goldberg GR, Jebb SA, Livingstone MB, Cole TJ, Prentice AM. Critical evaluation of energy intake data using fundamental principles of energy physiology: 2. Evaluating the results of published surveys. Eur J Clin Nutr 1991; 45: 583-99. 
44. Becker W. Dietary habits and nutrient intake in Sweden 1989. Methods and results (English summary). National Food Authority, Uppsala, 1994.

45. Andersen NL, Fagt S, Groth MV, et al. Danish dietary habits 1995 (English summary). Report No. 235, National Food Authority, Copenhagen, 1996.

46. Haraldsdottir J, Holm L, Jensen JH, Møller A. Dietary habits of the Danes 1985. 1. Main results (English summary). Report No. 136, National Food Authority, Copenhagen, 1986.

47. Steingrimsdottir L, Sigurdsson G Jr, Sigurdsson G. Nutrition and serum lipids in Iceland. Scand J Nutr 1995; 39: $138-41$.

48. Kleemola P, Virtanen M, Pietinen P. The 1992 dietary survey of Finnish adults. Publications of the National Public Health Institute, B2/1994. National Public Health Institute, Helsinki, 1994.

49. Bjartveit K, Foss OP, Gjervig T.The cardiovascular disease study in Norwegian counties. Results from first screening. Acta Med Scand 1983; 675 (Suppl): 1-184.

50. Hjertesaken. Rapport om hjerte-karundersøkelsen i Rogaland - 4. runde. Statens helseundersøkelser, Oslo, mai 1999.

51. Kohlmeier L, Helsing E, Kelly A, et al. Nutritional surveillance as the backbone of national nutrition policy: recommendations of the IUNS committee on nutritional surveillance and programme evaluation in developed countries. Eur J Clin Nutr 1990; 44: 771-81.

52. Hulshof KFAM, Løwik MRH. Nutritional surveillance in industrialized countries. Chapter 2 in: Assessment of variety, clustering and adequacy of eating patterns. Dutch National Food Consumption Survey. Thesis, Maastricht, 1993.

53. Briefel RR. Assessment of the US diet in national nutrition surveys: national collaborative efforts and NHANES. Am J Clin Nutr 1994; 59 (Suppl 1): 164S-7S.

54. Guenther PM. Research needs for dietary assessment and monitoring in the United States. Am J Clin Nutr 1994; 59 (1 Suppl): 168S-70S.

55. Haraldsdottir J, Holm L, Jensen H. Food consumption of the population. Trends followed via telephone interviews (in Danish). Ugeskr Laeger 1996; 158: 7402-6.

56. Becker W. Comparison of FAO, OECD and Swedish per capita statistics for foods (in Swedish). Jordbruksekonomiska meddelanden 1988; 50: 272-89.

57. Becker W, Berge S, Groth M, et al. Comparison of per capita statistics for foods in the Nordic countries (in Swedish). Report to Nordic working group for dietary and nutritional matters. Nordic Council og Ministers, Uppsala, September 1992.

58. Derry BJ, Buss DH. The British National Food Survey as a major epidemiological resource. Br Med J 1984; 288: $765-7$.

59. U.S. Department of Health and Human Services. The Surgeon General's Report on Nutrition and Health. DHHS Publication No. 88-50210. Public Health Service, Washington DC, 1988.

60. Trichopoulou A, Lagiou P (eds). Methodology for the exploitation of HBS food data and results on food availability in 5 European countries. COST action 99. DAFNE I. Luxembourg: Office for Official publications of the European Communities, 1997.

61. European Food Consumption Method. Prosjekt 1998/IND/2024 under EC Programme for Health Monitoring. 